\title{
Association of acanthosis nigricans and skin tags with insulin resistance
}

Associação de acantose nigricante e acrocórdons à resistência insulínica

\author{
Mariana Tremel Barbato ${ }^{1}$ \\ Ana Kris da Silva ${ }^{3}$ \\ Marina Bensen Guerine ${ }^{3}$
}

\author{
Paulo Ricardo Criado ${ }^{2}$ \\ Evelyne Averbeck ${ }^{3}$ \\ Naiana Bittencourt de Sá ${ }^{3}$
}

\begin{abstract}
Insulin resistance is a metabolic disorder in which target cells fail to respond to normal levels of circulating insulin. Insulin resistance has been associated with presence of acanthosis nigricans and acrochordons. It is known that early diagnosis and early initial treatment are of paramount importance to prevent a series of future complications. These dermatoses may represent an easily identifiable sign of insulin resistance and non-insulin-dependent diabetes.
\end{abstract}

Keywords: Acanthosis nigricans; Diabetes mellitus, type 2; Insulin resistance; Metabolic syndrome X

\begin{abstract}
Resumo: A resistência insulínica é uma alteração metabólica caracterizada por falhas das células-alvo em responder aos níveis normais de insulina circulante. A resistência insulínica já foi relacionada à presença de acantose nigricante e de acrocórdons. Sabe-se que o diagnóstico e o início do tratamento precoce são de suma importância para prevenção de uma série de manifestações futuras. Estas dermatoses podem representar um sinal facilmente identificável para rastreamento de resistência à insulina e do diabetes mellitus não insulinodependente.

Palavras-chave: Acantose nigricans; Diabetes mellitus tipo 2; Resistência à insulina; Síndrome X metabólica
\end{abstract}

Received on 13.02.2011.

Approved by the Advisory Board and accepted for publication on 13.03.2011.

* Study conducted at the Dermatology Service of Polydoro Ernani de São Thiago University Hospital - Federal University of Santa Catarina (HU - UFSC) Florianopolis (SC) Brazil.

Financial Support: None / Suporte Financeiro: Nenhum

Conflict of Interest: None / Conflito Interesses: Nenbum

MSc in Medicine: Medical Sciences, Federal University of Rio Grande do Sul (Universidade Federal do Rio Grande do Sul - UFRGS) - Dermatologist, preceptor of residency in dermatology at Polydoro Ernani de São Thiago University Hospital (Hospital Universitário Polydoro Ernani de São Thiago) - Federal University of Santa Catarina (Universidade Federal de Santa Catarina - HU - UFSC) - Florianópolis (SC), Brazil.

PhD in Dermatology, Medicine School of the University of São Paulo (Faculdade de Medicina da Universidade de São Paulo - USP) - Dermatologist at the Clinics Hospital, Medicine School of the University of São Paulo (HC - FMUSP) - Sao Paulo (SP), Brazil.

Dermatologist - Specialist in Dermatology, Federal University of Santa Catarina (UFSC) - Florianopolis (SC), Brazil.

(C)2012 by Anais Brasileiros de Dermatologia 


\section{INTRODUCTION}

\subsection{Insulin Resistance}

Insulin resistance (IR) is a metabolic disorder in which target cells fail to respond to normal levels of circulating insulin, which results in compensatory hyperinsulinemia in an attempt to obtain an appropriate physiological response. ${ }^{1}$ It is especially found in individuals with diabetes mellitus (DM) type 2, decompensated type $1 \mathrm{DM}$, diabetic ketoacidosis and obesity. $^{2.5}$ In normal populations, IR occurs in 20 to $25 \%$ of the individuals. ${ }^{2,5}$

There are three types of IR: (i) Type A, caused by a reduced number and dysfunction of insulin receptors; (ii) type $\mathrm{B}$, caused by formation of antibodies against insulin receptors; and (iii) Type $\mathrm{C}$, which corresponds to a post-receptor defect. Obese patients and patients with polycystic ovary syndrome (PCOS) have type-A insulin resistance. ${ }^{6}$

DM occurs when insulin secretory capacity fails to reduce serum glucose. Insulin concentrations are generally higher in early type 2 diabetes, but the levels are not enough to compensate for insulin resistance due to a pancreatic beta cell defect. ${ }^{6}$

Insulin resistance increases during puberty and appears to be related to fat accumulation.

The insulin receptor belongs to the family of tyrosine kinase receptors, which includes the insulinlike growth factor (IGF), epidermal growth factor (EGF), fibroblast growth factor (FGF), platelet-derived growth factor, colony-stimulating factor I and several cytokine receptors. ${ }^{8,9}$ A high concentration of insulin results in a direct and indirect activation of IGF-1 receptors in keratinocytes and fibroblasts, leading to their proliferation. Other mediators can contribute, including other tyrosine kinase receptors such as EGFR - epithelial growth factor receptor - and FGFRfibroblast growth factor receptor. ${ }^{10}$

Hyperinsulinemia increases ovarian androgen production and IGF-1 and 2 in the liver. Insulin and IGF-I increase the activity of 17-hydroxylase in the ovaries, causing excessive production of androgens, especially of 17-hydroxyprogesterone (17-OHP) (Figure 1). Indirectly, insulin potentiates the action of LH in the ovaries. ${ }^{11,12}$ Another effect of the increase in insulin levels is a decrease in the hepatic production of SHBG (a sex-hormone carrier protein) and IGFBP-I (IGF-1 carrier protein or IGF-1 binding protein), contributing to greater action of free testosterone (FT) and IGF-1, respectively, in target cells. In vitro studies have shown that insulin and IGF-1 may also stimulate growth of the hair follicle and act together with androgens when playing this role. Hyperinsulinemia can also increase the action of 5-alpha reductase, leading to increased conversion of testosterone into dihydrotestosterone. ${ }^{13}$

There are several methods of assessment and diagnosis of IR. ${ }^{1,5,14-15}$ Fasting insulin levels have been used to assess IR, since it is easy to use this method in large populations. Homeostasis Model Assessment (HOMA) is a mathematical model that predicts IR by simply measuring fasting glucose and insulin levels. Also, it has good correlation with the hyperinsulinemic-euglycemic clamp method, which is considered the gold standard for the measurement of IR. ${ }^{1,14-15}$ Its calculation for IR is done by multiplying the amount of glucose (in mmol) by the amount of insulin (in $\mathrm{uU} / \mathrm{mL}$ ) and dividing this result by 22.5 (HOMA-IR = glucose $(\mathrm{mmol}) \mathrm{x}$ insulin $(\mathrm{uU} / \mathrm{mL}) \div 22.5) .{ }^{1,5,14-15} \mathrm{IR}$ is

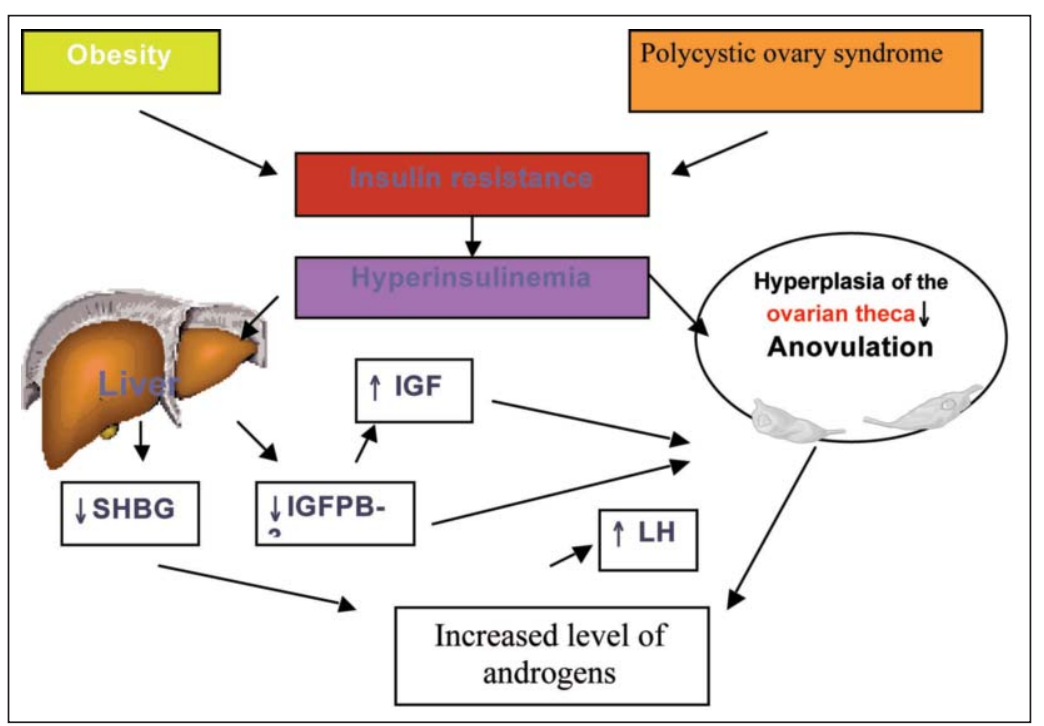

FIGURE 1: Schematic demonstration of the effects of hyperinsulinemia in various organs and tissues 
diagnosed when the result is greater than $2.71 .^{1}$ In women, insulin resistance is considered when the result exceeds the $75^{\text {th }}$ percentile (1.80). ${ }^{1}$ Direct methods of assessment of IR include the insulin tolerance test (KITT), insulin suppression test and hyperinsulinemic-euglycemic clamp techniques. The costs of their development, however, limit their use. ${ }^{1}$

\subsection{Acanthosis Nigricans}

Acanthosis nigricans (AN) was initially proposed by Unna and then published by Pollitzer and Janovsky in 1890. It is characterized by symmetrical, hyperpigmented, velvety lesions, which can occur anywhere in the body, but especially in the armpits, groin, neck, antecubital and popliteal fossae and umbilical region (Figure 2). Less often it affects eyelids, palms, soles of the feet, nipples and phalanges (Figure 3). ${ }^{16}$ In rare cases, it can affect the mucosa of the mouth, respiratory mucosa and genital region. These lesions may be skin-colored or brownish and may vary between $1 \mathrm{~mm}$ and $1 \mathrm{~cm} .{ }^{6}$

Curth clinically classified AN as benign, malignant, syndromic and pseudo-acanthosis nigricans (Table 1). ${ }^{17}$ The term pseudo-acanthosis nigricans was reserved for cases in which the dermatosis affected obese individuals who had no underlying endocrinopathies. In these cases, AN was attributed to excessive local friction and sweat. ${ }^{17,18}$ However, later studies showed that AN was a marker for insulin resistance in obese patients when compared with control groups with similar degree of obesity. ${ }^{19}$ With these findings, the term pseudo-acanthosis nigricans became obsolete.

More recently, Sinha and Schwartz have proposed a classification for AN as shown in Table 1. ${ }^{20}$
The dermatological manifestation is similar in all forms of $\mathrm{AN}$, but $\mathrm{AN}$ tends to be less pronounced in the juvenile type. The benign genetic form is rare and it is an autosomal dominant disorder with incomplete penetrance. It can be present at birth or develop during childhood. In this form, no endocrinopathy is found. ${ }^{6}$

Endocrinopathies are the major causes of AN, and obesity is the most common disorder, often associated with hyperinsulinism, diabetes mellitus and insulin resistance. Other endocrine disorders associated with AN are described, such as Cushing's syndrome, polycystic ovaries, thyroid diseases, hirsutism, Addison's disease, acromegaly, among others, some of which occur with insulin resistance. ${ }^{21}$

The mechanism through which insulin resistance causes acanthosis is complex. The significant presence of IR produces compensatory hyperinsulinemia. Increased serum insulin levels interact with insulinlike growth factor receptors (IGF-1) triggering proliferation of keratinocytes and fibroblasts (Figure 4). AN is caused by factors that stimulate epidermal keratinocyte and dermal fibroblast proliferation. In forms associated with malignancy, substances secreted by the tumor are thought to act as stimulating factors. ${ }^{16}$ It is postulated that TGF-alpha, which is produced by the tumor and is similar to EGF, is important in the genesis of malignant AN. ${ }^{6,16,22}$

The epidermal growth factor (EGF) is an important mediator of keratinocyte growth in vitro, and both the EGF receptor (EGF-R) and EGF are found in excessive amounts in the hyperproliferative epidermis. EGF needs to interact with insulin-like growth factor/somatomedin (IGF-1) or with high doses of insulin for keratinocyte proliferation. The IGF-I recep-

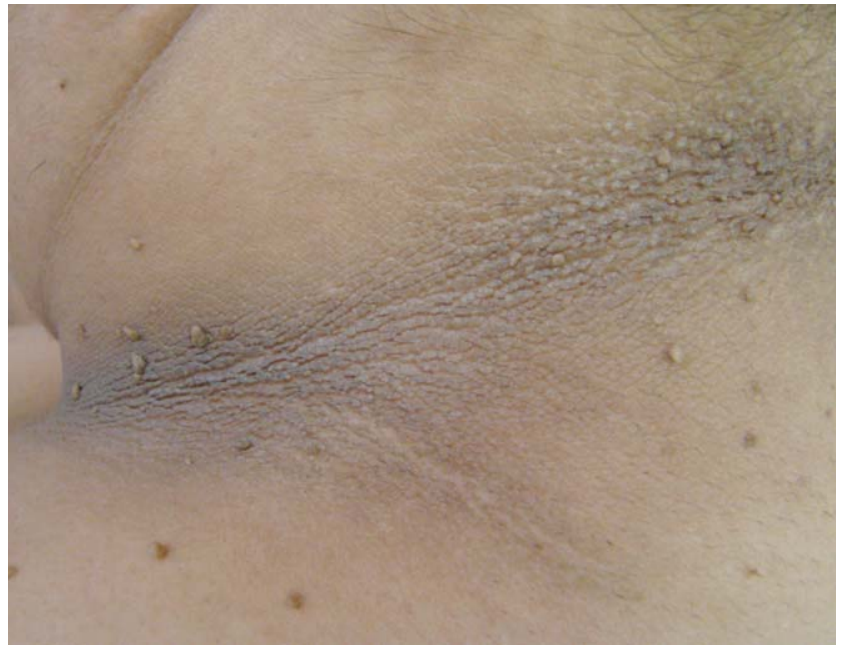

Figure 2: Acanthosis nigricans and skin tags

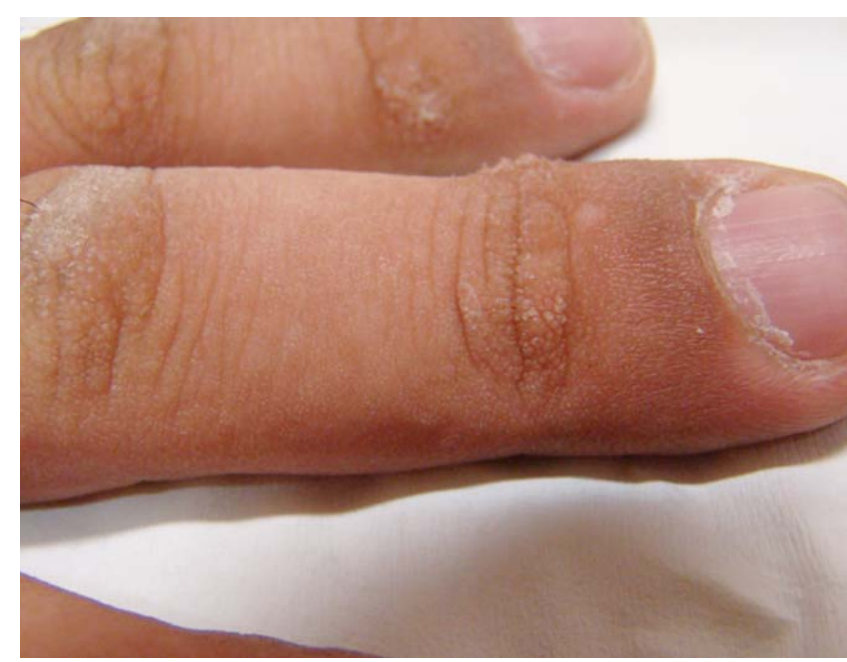

Figure 3: Acanthosis nigricans; acral 


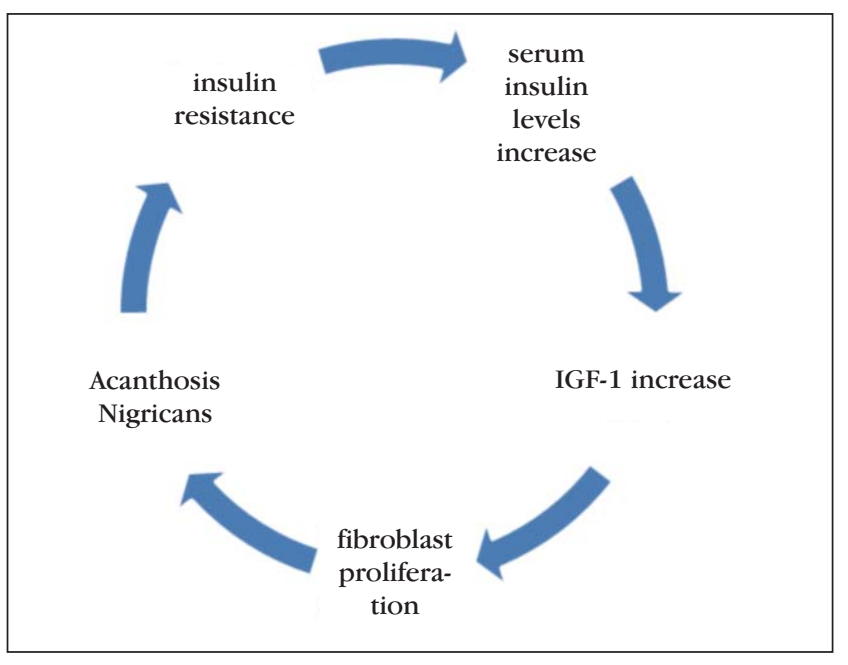

FIGURE 4: Triggering mechanism of acanthosis nigricans lesions associated with endocrinopathy

tor is located in the basal layer of the epidermis, suggesting participation of IGF-1 and EGF in the regulation of epidermal growth and in the pathogenesis of hyperproliferative skin diseases. ${ }^{23}$

The prevalence of AN in unselected populations varies from 7 to $74 \%$, according to age, race, frequency of type, degree of obesity and concomitant endocrinopathy. ${ }^{24,25}$ In a study involving 34 obese individuals of both sexes in a predominantly black population (59\%), Hud et al. reported prevalence of AN in $74 \%$ of the patients and demonstrated clear predominance of AN in dark-skinned and black women in relation to white women. ${ }^{19}$

Stoddart et al. (2002) and Kong et al. (2007) recognized $\mathrm{AN}$ as an independent risk factor associated with hyperinsulinemia, with the development of DM. ${ }^{26,27}$ Kong showed that children with a family history of type 2 diabetes presented AN more often and that acanthosis was more frequent in patients with hypertension and high BMI. ${ }^{27}$ This author concluded that early detection of AN may be important in identifying individuals at risk for type 2 diabetes, allowing the doctor to advise a different lifestyle, thus reducing the risk of developing the disease. ${ }^{27}$

Several other studies have demonstrated an association between presence of AN and insulin resistance, such as a study by Yamazaki et al. (2003). These authors found a positive association between these elements when investigating it among obese Japanese children. ${ }^{28}$ Stuart studied 89 African-Americans with AN and observed a frequency of $21.3 \%$ of type II diabetes. ${ }^{23}$ Burke et al. also observed higher levels of fasting insulin in patients with AN. ${ }^{29}$

Sadeghian et al. (2009) investigated the presence of insulin resistance in obese women with and wit- hout AN, and the skin lesions proved to be a marker for insulin resistance. The mean value of HOMA-IR was $3.5+-1.9$ and $2.6+-0.9 \mathrm{um} / \mathrm{ml}$ in patients with and without acanthosis nigricans, respectively $(\mathrm{p}$ $<0.05$ ). There was no significant statistical difference in terms of lipid profile, triglycerides and presence of hypertension between the two groups. ${ }^{22}$

Copeland et al. (2006) investigated the association between AN and insulin resistance in children and found that the intensity of the dermatological presentation was correlated with the values of HOMA. ${ }^{30}$ The same authors observed that AN showed to be an independent risk factor for the development of insulin resistance. ${ }^{30}$ Wiegan et al. (2004) observed a sample of 491 obese children and adolescents and also concluded that the presence of AN is associated with higher HOMA values. ${ }^{31}$ In addition to showing that the HOMA index followed the intensity of AN, Araújo et al. (2002) indicated that these changes in insulin levels are found more often in dark-skinned and black individuals, based on their sample of obese women. Thus, the authors suggest that AN is a marker of high risk for developing non insulin-dependent diabetes mellitus. This study did not find statistical differences in the proportions of total cholesterol, HDL, LDL and triglycerides in the population with and without $\mathrm{AN} .{ }^{32}$ AN also showed to be more common in women with polycystic ovary syndrome (PCOS). Charnvises et al. confirmed in their study that AN is a cutaneous marker of the presence of glucose intolerance and insulin resistance in women with PCOS. ${ }^{33}$

Hirschler et al. (2002) disagree in their study of 1,250 Hispanic children, stating that AN could reflect obesity rather than represent an independent factor for insulin resistance. ${ }^{33}$ In this study, the BMI of patients with AN was higher, but insulin resistance and HOMA did not change compared to those without acanthosis. ${ }^{34}$

Caceres et al. (2008) studied the relationship between insulin resistance and AN in obese children and adolescents and found no statistically significant association, since they found AN in $70 \%$ of the patients with insulin resistance and in $54 \%$ of the patients sensitive to insulin. ${ }^{35}$ Scott suggested that AN in obese children is a marker of metabolic dysfunction, since these patients presented an increased risk of developing type 2 diabetes. In the same study, Creactive protein (CRP) levels were higher in the group with AN, suggesting increased systemic inflammatory response. This finding could not be confirmed because the method used for PCR detection was not the same in all cases. ${ }^{36}$

Hardin et al. (2006) suggested investigation of $\mathrm{DM}$ focused on the presence of $\mathrm{AN}$ at the primary care level. ${ }^{37}$ Guran et al. (2008) suggest that AN may be a 
Chart 1: Classification of acanthosis nigricans

Classification of acanthosis nigricans (AN) according to Curth:

Type I - malignant AN (cutaneous paraneoplastic syndrome)

Type II - benign AN/ true AN (present at birth or onset in childhood)

Type III - pseudo AN (association with endocrinopathies)

Type IV - drug-induced AN
Classification of acanthosis nigricans (AN) according to Sinha and Schwartz:

obesity-associated AN (formerly termed pseudo AN)

benign AN

syndromic AN

malignant AN

unilateral AN

acral AN

drug-induced AN

mixed AN marker of metabolic syndrome (Syndrome $\mathrm{X}$ ) in obese children. Thus, children with this finding need to be examined for syndrome $\mathrm{X} .{ }^{38}$ AN becomes a signal for tracking insulin resistance and non-insulin-dependent DM, with consequent changes in lifestyle and establishment of early treatment. ${ }^{27}$

Miura showed that AN is an important marker of obesity associated with high body mass index, with genes B2ADR Gly16 and B3ADR Arg 64 being synergistically associated with AN in obese children and adolescents. ${ }^{39}$ The same group demonstrated higher levels of alanine aminotransferase (ALT), reflecting increased fat accumulation (steatosis) in the liver of patients with AN. ${ }^{40}$

Acanthosis can be treated simply by improving lifestyle with regular physical activity and a proper diet. For more extreme cases, we can use medication such as octreotide (somastotatin analogue), analogues of cholecalciferol (vitamin D3, topical calcipotriol, retinoid and metformin). ${ }^{6}$ Metformin reduces glucose production by increasing peripheral insulin responsiveness. ${ }^{41}$ The combined use of metformin and thiazolidiones, which increase sensitivity to insulin in peripheral muscles, also presented good results. ${ }^{42}$

In Texas (USA), the regional Education Agency created a program for detection of type 2 diabetes in $1^{\text {st }}, 3^{\text {rd }}, 5^{\text {th }}$, and $7^{\text {th }}$ graders in public and private schools, which consisted in assessing the skin of these students for AN between 1999 and 2003. The program was simple and detection of the condition was easy, since the exam was only clinical, not dependent on invasive procedures. The children were diagnosed and their parents were advised to take them to a doctor for a thorough examination. ${ }^{43}$

Sinha and Schwartz (2007) suggest how to approach children with AN in their work (Figure 5). ${ }^{20}$

\subsection{Skin tags}

Skin tags are common tumors that usually affect middle-aged individuals and the elderly. They usually occur on the neck, armpits and groin. They are small soft and pedunculated protrusions. ${ }^{44-46}$ The lesions may be brown or skin-colored and range from $1 \mathrm{~mm}$ to $1 \mathrm{~cm}$ in diameter. ${ }^{47}$ Histologically, they are characterized by loss of collagen fibers and dilated blood capillaries. ${ }^{48}$ After the age of 40 , the frequency of skin tags is $37 \%$, being greater than in the general population, among which the frequency is 20 to $25 \% .{ }^{49}$ Banik states that, although $46 \%$ of the general population has skin tags, only $14.4 \%$ have eight or more lesions on the body. ${ }^{48}$ In 2006, according to the region of the country, it was estimated that between $0.9 \%$ and $1.2 \%$ of the dermatologic diagnoses in Brazil referred to skin tags. ${ }^{50}$

Multiple skin tags are frequently found in obese and non-insulin-dependent diabetic individuals; insulin resistance is an abnormality underlying the two conditions. The proliferation of fibroblasts that occurs in skin tags seems to be due to hyperinsulinemia, via activation of the insulin-like growth factor (IGF-1) receptors present on their surfaces. Skin tags are closely related to fasting insulin levels. ${ }^{44}$

In recent years, some studies have tried to show the correlation between skin tags and insulin resistance, their serum levels and the levels of IGF-1. According to Jowkar et al., insulin levels in patients with skin tags are far greater than in control individuals, suggesting the importance of insulin in their pathogenesis. However, a correlation with levels of IGF-1 has not been shown yet. ${ }^{46}$ Similar to acanthosis nigricans, insulin does not appear to be the only mediator in the formation of skin tags, but it is certainly the most important one in the formation of these lesions. ${ }^{51}$ 


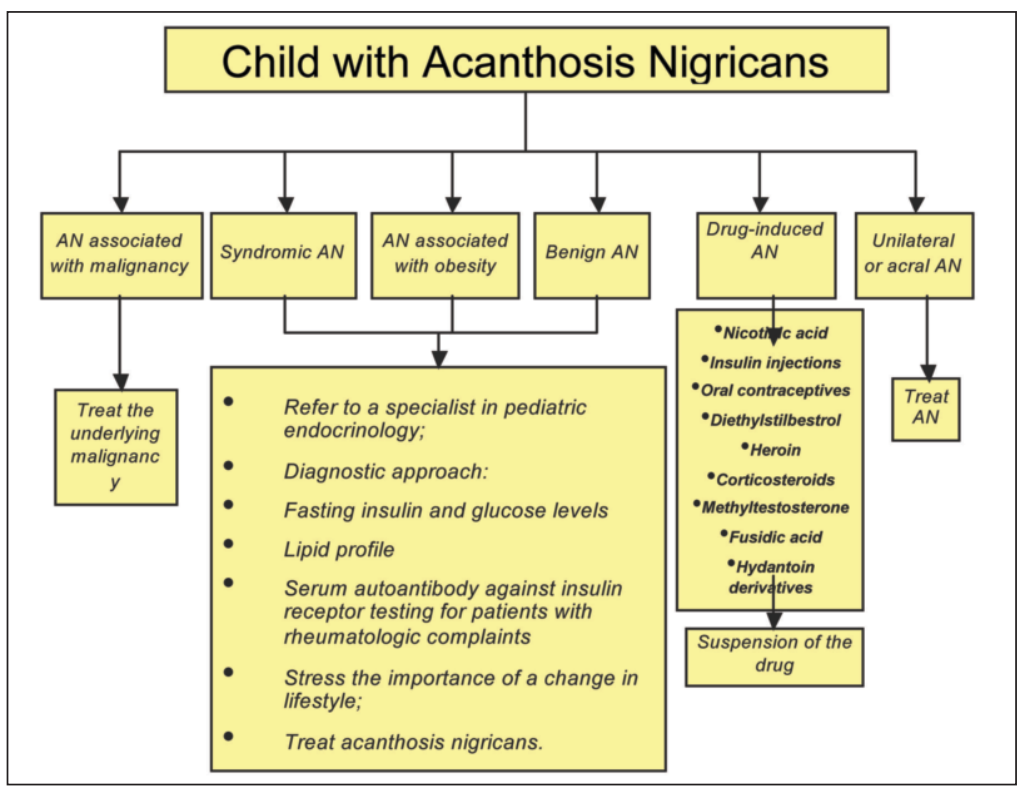

Figure 5: Approach of children with acanthosis nigricans ${ }^{20}$
In individuals who have multiple skin tags, it is important to suspect of a disorder in the metabolism of carbohydrates, either in the form of insulin resistance or diabetes mellitus. ${ }^{45,46}$

Rasi et al. demonstrated that patients with more than 30 skin tags are at higher risk of having diabetes (52\%), although BMI was not correlated with the number of skin tags in this study. ${ }^{52}$

No correlation was found between the topography of skin tags and carbohydrate metabolism, except for skin tags in the inframammary region in women. ${ }^{51}$

Crook reported four patients with multiple skin tags, and all patients had increased levels of serum triglycerides and reduced HDL cholesterol levels. ${ }^{53}$ Multiple skin tags (more than 8 lesions) were more sensitive than AN when identifying changes in carbohydrate metabolism, but less specific. ${ }^{52}$ Therefore, presence of skin tags is a clue for detection of hyperinsulinemia, which is considered the foundation for syndrome $\mathrm{X} .{ }^{51}$

Tamega et al. identified an independent association between presence of more than five skin tags and an increase of 1.4 units in the HOMA-IR index in dermatological patients. The significant association with BMI and hypertriglyceridemia found in this study strengthens the concept that skin tags may constitute markers of insulin resistance. ${ }^{54}$

HPV infections are associated with the genesis of several benign lesions. In a study by Dianzani (1998), the presence of HPV 6/11 DNA was detected in $88 \%$ of skin tags; however, the amount of DNA was small in these cases. ${ }^{55}$ Gupta performed PCR for HPV types 6 and 11 in skin tags and found the presence of
HPV 6/11 DNA in 48.6\% of the soft fibromas. However, more studies are needed to confirm the role of HPV in the formation of skin tags. ${ }^{56}$

Presence of skin tags is associated with pregnancy, acromegaly, intestinal polyps, dyslipidemia and several syndromes: polycystic ovary, Birt-Hogg-Dube and Cowden syndromes. ${ }^{57}$ Variations in estrogen levels are implicated in the etiology of these lesions. ${ }^{54}$

Rezzonico et al. concluded that individuals with skin tags have a high prevalence of thyroid nodules and thyroid with increased volume. ${ }^{58}$ This is because skin tags and thyroid changes may be associated with high levels of circulating insulin. ${ }^{58}$

\section{CONCLUDING REMARKS}

AN lesions and skin tags should never be ignored, since they bring information about internal diseases and, therefore, can offer some guidance as to how to proceed about these diseases, preventing a series of future morbidities such as diabetes and atherosclerotic diseases.

Although often disregarded by patients, since they are asymptomatic lesions, these dermatoses are of great importance and cannot go unnoticed in the clinical examination, since they can serve as indicators of the need to measure laboratory data that may lead to a diagnosis of insulin resistance.

IR, like smoking, alcohol abuse and violence in traffic, represent one of the most important modifiable factors for promoting health and reducing mortality in general. ${ }^{54}$

Insulin resistance has been associated with AN and $\mathrm{AC}$, and it is known that early diagnosis and early treatment are of paramount importance to prevent a 
series of future manifestations. Reduction of insulin action may be accompanied by a group of metabolic disorders such as hypertension, hypertriglyceridemia, reduced $\mathrm{HDL} / \mathrm{cholesterol} \mathrm{levels,} \mathrm{carbohydrate} \mathrm{intole-}$ rance, central obesity, increased plasminogen activator inhibitor-1 concentrations (fibrinolytic disorders), hyperuricemia and atherosclerotic cardiovascular disease. This set of changes is known as insulin resistance syndrome or metabolic syndrome. ${ }^{2,5}$ Therefore, AN becomes an easy signal for tracking insulin resistance and non-insulin-dependent DM, with implications regarding changes in lifestyle and adoption of early treatment.

\section{REFERENCES}

1. Vasques ACJ, Rosado LEFPL, Alfenas RCG, Geloneze B. Análise Crítica do Uso dos Índices do Homeostasis Model Assessment (HOMA) na Avaliação da Resistência à Insulina e Capacidade Funcional das Células $\beta$-Pancreáticas. Arq Bras Endrocrinol Metab. 2008;52:32-9.

2. Reaven GM. Banting lecture 1988. Role of insulin resistance in human disease. Diabetes. 1988;37:1595-607.

3. Yki-Järvinen $\mathrm{H}$, Koivisto VA. Natural course of insulin resistance in type 1 diabetes. N Engl J Med. 1986;315:224-30.

4. Kissebah AH. Insulin resistance in visceral obesity. Int J Obes. 1991;15 (Suppl 2):109-15.

5. Geloneze B, Tambascia MA. Avaliação laboratorial e diagnóstico de resistência insulínica. Arq Bras Endocrinol Metab. 2006:50:208-15.

6. Hermanns-Le T, Scheen A, Pierard GE. Acanthosis nigricans associated with insulin resistance: pathophysiology and management. Am J Clin Dermatol. 2004;5:199-203.

7. Greenberg AS, McDaniel ML. Identifying the links between obesity, insulin resistance and beta-cell function: potential role of adipocyte-derived cytokines in the pathogenesis of type 2 diabetes. Eur J Clin Invest. 2002;32 Suppl 3:24-34.

8. Yarak S, Bagatin E, Hassun KM, Parada MOAB, Talarico Filho S. Hiperandrogenismo e pele: síndrome do ovário policístico e resistência periférica à insulina. An Bras Dermatol. 2005:80:395-410.

9. Dunaif A, Xia J, Book CB, Schenker E, Tang Z. Excessive insulin receptor serine phosphorylation in cultured fibroblasts and in skeletal muscle. A potential mechanism for insulin resistance in the polycystic ovary syndrome. J Clin Invest. 1995:96:801-10.

10. Higgins SP, Freemark M, Prose NS . Acanthosis nigricans: A practical approach to evaluation and management. Dermatol Online J. 2008:14: 2 .

11. Kidson W. Polycystic ovary syndrome: a new direction in treatment. Med J Aust. 1998:169:537-40.

12. Goodarzi MO, Erickson S, Port SC, Jennrich RI, Korenman SG. $\beta$-cell function: a key pathological determinant in polycystic ovary syndrome. J Clin Endocrinol. Metab. 2005:90:310-5.
13. Nermeen S.A. Fattah A Darwish Y.W. Is there a role for insulin resistance in nonobese patients with idiopathic hirsutism? Br J Dermatol. 2009;160:1011-5.

14. Geloneze B, Vasques AC, Stabe CF, Pareja JC, Rosado LE, Queiroz EC, et al. HOMA1-IR and HOMA2-IR indexes in identifying insulin resistance and metabolic syndrome - Brazilian Metabolic Syndrome Study (BRAMS). Arq Bras Endocrinol Metab. 2009;53:117-9.

15. Wallace TM, Levy JC, Matthews DR. Use and abuse of HOMA modeling. Diabetes Care. 2004;27:1487-95.

16. Schwartz RA. Acanthosis nigricans. J Am Acad Dermatol. 1994;31:1-19.

17. Curth HO. Classification of acanthosis nigricans. Int J Dermatol. 1976;15:592-3.

18. Brown J, Winkelmann RK. Acanthosis nigricans: A study of 90 cases. Medicine (Baltimore). 1968;47:33-51.

19. Hud JA Jr, Cohen JB, Wagner JM, Cruz PD. Prevalence and significance of Acanthosis nigricans in an adult obese population. Arch Dermatol 1992;128:941-4.

20. Sinha S, Schwartz RA. Juvenile acanthosis nigricans. J. Am Acad Dermatol. 2007;57:502-8.

21. Araújo LMB, Viveiros AMC, Lopes RC, Viana AC, Fukui RT. Acanthosis nigricans em mulheres obesas de uma população miscigenada: um marcador de distúrbios metabólicos. An Bras Dermatol. 2002:77:537-43

22. Sadeghian G, Ziaie H, Amini M, Ali Nilfroushzadeh M. Evaluation of insulin resistance in obese women with and without acanthosis nigricans. J Dermatol. 2009;36:209-12.

23. Krane JF, Murphy DP, Carter DM, Krueger JG. Synergistic effects of epidermal growth factor (EGF) and insulin-like growth factor I/somatomedin C (IGF-I) on keratinocyte proliferation may be mediated by IGF-I transmodulation of the EGF receptor. J Invest Dermatol. 1991;96:419-24.

24. Stuart CA, Pate CJ, Peters EJ. Prevalence of Acanthosis nigricans in an unselected population. Am J Med. 1989;87:269-72.

25. Stuart CA, Smith MM, Gilkison CR, Shaheb S, Stahn RM. Acanthosis nigricans among native Americans: an indicator of high diabetes risk. Am J Publ Health. 1994; 84:1839-42

26. Stoddart ML, Blevins KS, Lee ET, Wang W, Blackett PR; Cherokee Diabetes Study 
Association of acanthosis nigricans with hyperinsulinemia compared with other selected risk factors for type 2 diabetes in Cherokee Indians: the Cherokee Diabetes Study. Diabetes Care. 2002;25:1009-14.

27. Kong AS, Williams RL, Smith M, Sussman AL, Skipper B, Hsi AC, et al. Acanthosis nigricans and diabetes risk factors: prevalence in young persons seen in southwestern US primary care practices. Ann Fam Med. 2007;5:202-8.

28. Yamazaki H, Ito S, Yoshida H. Acanthosis nigricans is a reliable cutaneous marker of insulin resistance in obese Japanese children. Pediatr Int. 2003;45:701-5

29. Burke PB, Hazuda HP, Hale DE, Stern MP. A quantitative scale of acanthosis nigricans. Diabetes Care. 1999;22:1655-9.

30. Copeland K, Pankratz K, Cathey V, Immohotichey P, Maddox J, Felton B, et al. Acanthosis Nigricans, insulin resistance (HOMA) and dyslipidemia among Native American children. J Okla State Med Assoc. 2006;99:19-24.

31. Wiegand S, Maikowski U, Blankenstein O, Biebermann H, Tarnow P, Grüters A. Type 2 diabetes and impaired glucose tolerance in European children and adolescents with obesity - a problem that is no longer restricted to minority groups. Eur J Endocrinol. 2004;151:199-206.

32. Araújo LM, Porto MV, Netto EM, Ursich MJ. Association of acanthosis nigricans with race and metabolic disturbances in obese women. Braz J Med Biol Res. 2002;35:59-64.

33. Charnvises K, Weerakiet S, Tingthanatikul Y, Wansumrith S, Chanprasertyothin S Rojanasakul A. Acanthosis nigricans: clinical predictor of abnormal glucose tolerance in Asian women with polycystic ovary syndrome. Gynecol Endocrinol. 2005;21:161-4.

34. Hirschler V, Aranda C, Oneto A, Gonzalez C, Jadzinsky M. Is acanthosis nigricans a marker of insulin resistance in obese children? Diabetes Care. 2002;25:2353.

35. Caceres M, Teran CG, Rodriguez S, Medina M. Prevalence of insulin resistance and its association with metabolic syndrome criteria among Bolivian children and adolescents with obesity. BMC Pediatr. 2008;8:31

36. Scott AT, Metzig AM, Hames RK, Schwarzenberg SJ, Dengel DR, Biltz GR. Acanthosis nigricans and oral glucose tolerance in obese children. Clin Pediatr. 2010;49:69-71

37. Hardin DS. Screening for type 2 diabetes in children with acanthosis nigricans. Diabetes Educ. 2006;32:547-52.

38. Guran T, Turan S, Akcay T, Bereket A. Significance of acanthosis nigricans in childhood obesity. J Paediatr Child Health. 2008:44:338-41.

39. Miura N, Ikezaki A, Iwama S, Matsuoka H, Ito K, Sugihara S. Genetic factors and clinical significance of acanthosis nigricans in obese Japanese children and adolescents. Acta Pediátrica. 2006;95:170-5.

40. Ikezaki A, Miura N, Kikuoka N, Kim HS, Matsuoka H, Ito K, et al. Clinical characteristics of obese Japanese children with acanthosis nigricans. Clin Pediatr Endocrinol. 2001:10:47-52.

41. DeFronzo RA. Pharmacologic therapy for type 2 diabetes mellitus. Ann Intern Med 1999:131:281-303

42. Roemmich JN, Clark PA, Lusk M, Friel A, Weltman A, Epstein LH, et al. Puberta alterations in growth and body composition. VI. Pubertal insulin resistance: relation to adiposity, body fat distribution and hormone release. Int J Obes Relat Metab Disord. 2002;26:701-9

43. University of Texas. [Internet]. Texas Risk Assessment Advisory for type 2 Diabetes in Children. [cited 2010 jan 10]. Available from: https://rfes.utpa.edu/
44. Mathur SK, Bhargava P. Insulin resistence and skin tags. Dermatology. 1997:195:184

45. Demir S, Demir Y. Acrochordon and impaired carbohydrate metabolism. Acta Diabetol. 2002;39:57-59.

46. Jowkar F, Fallahi A, Namazi MR. Is there any relation between serum insulin and insulin-like growth factor-I in non-diabetic patients with skin tag? J Eur Acad Dermatol Venereol. 2010;24:73-4

47. Pariser RJ. Benign neoplasms of the skin. Méd Clin North Am. 1998;82:1285-307.

48. Banik R, Lubach D. Skin tags: localization and frequencies according to sex and age. Dermatologica. 1987;174:180-3.

49. Turner R, Holman RR, Matthews D, Hockaday TR, Peto J. Insulin deficiency and insulin resistance interaction in diabetes: estimation of their relative contribution by feedback analysis from basal plasma insulin and glucose concentrations. Metabolism. 1979;28:1086-96.

50. Sociedade Brasileira de Dermatologia. Perfil nosologico das consultas dermatologicas no Brasil. An Bras Dermatol. 2006;81:549-58.

51. Sudy E, Urbina F, Maliqueo M, Sir T. Screening of glucose/insulin metabolic alterations in men with multiple skin tags on the neck. J Dtsch Dermatol Ges. 2008;6:852-6

52. Abbas R, Soltani-Arabshahi R, Shahbazi N. Skin tag as a cutaneous marker for impaired carbohydrate metabolism: a case-control study. Int J Dermatol. 2007;46:1155-9.

53. Crook MA. Skin tags and the atherogenic lipid profile. J Clin Pathol. 2000;53:873-4.

54. Tamega AA, Aranha AMP, Guiotoku MM, Miot LDB, Miot HA. Associacao entre acrocordons e resistencia a insulina. An Bras Dermatol. 2010;85:25-31.

55. Dianzani C, Calvieri S, Pierangeli A, Imperi M, Bucci M, Degener AM. The detection of human papillomavirus DNA in skin tags. Br J Dermatol. 1998;138:649-51.

56. Gupta S, Gupta S, Aggarwal R, Arora S. Human papillomavirus and skin tags: Is there any association? Indian J Dermatol Venereol Leprol. 2008;74:222-5.

57. Piette AM, Meduri B, Fritsch J, Fermanian J, Piette JC, Chapman A. Do skin tags constitute a marker for colonic polyps? A prospective study of 100 asymptomatic patients and metaanalysis of the literature. Gastroenterology. 1988:95:1127-9.

58. Rezzónico J, Rezzónico M, Pusiol E, Pitoia F, Niepomniszcze H. High prevalence of thyroid nodules in patients with achrocordons (skin tags). Possible role of insulinresistance. Medicina. 2009;69:302-4.

59. Guran T, Turan S, Akcay T, Bereket A. Significance of acanthosis nigricans in childhood obesity. J Paediatr Child Health. 2008;44:338-341.

\section{MAILING ADDRESS / ENDEREÇO PARA CORRESPONDÊNCIA : Mariana Tremel Barbato Rua Alves de Brito, 346 - sala 101 - Centro CEP: 88015440 - Florianópolis - SC, Brazil}

Phone.: (55) 4832236891

Email:contato@marianabarbato.com.br 